\title{
Menakar Mahar: Studi tentang Masyarakat Santri di Desa Karangbesuki Sukun, Kota Malang
}

\author{
Ahmad Izzuddin \\ azharzudin@gmail.com \\ Universitas Islam Negeri Maulana Malik Ibrahim Malang
}

\begin{abstract}
Islamic marriage rules in practice form values that are lived out and practiced in the context of cultural society so that they emerge as symbols as a form of the dialectical process between religious values and cultural values. As an example of the concept of dowry in Islam which has two dimensions, the universality of the values adhered to by all its adherents and also the value locality that is formed from the dialectical process that occurs between religious teachings and the local culture of the adherents. This was seen in the santri community in Karangbesuki Village, Malang City in determining the dowry in their marriage by identifying aspects of the normative dowry in the fiqh that they embraced into their marital culture.
\end{abstract}

Key words: Islamic marriage, Karangbesuki, Dowry, Santri, Malang

\section{Pendahuluan}

Islam merupakan kerangka konseptual keagaamaan yang bersifat humanis di mana keselamatan dan kedamaian manusia menjadi tujuan sentral dalam ajaran-ajaran humanis teosentrisnya. Inti tauhidullah (keesaan Tuhan) dalam ajarannya diarahkan untuk menciptakan kemaslahatan kehidupan dan peradaban (tamaddun) umat manusia seluruhnya. Dalam implementasinya, prinsip humanisme teosentris akan membentuk nilai-nilai yang dihayati dan dipraktekkan dalam konteks masyarakat budaya. Dengan demikian akan muncul simbolsimbol sebagai bentuk dari terjadinya proses dialektika antara nilai agama dengan tata nilai budaya (Kuntowijoyo, 1996: 160). Oleh karena itu, Islam memiliki dua dimensi, yaitu universalitas nilai yang dianut oleh seluruh penganutnya dan juga lokalitas nilai yang terbentuk dari proses dialektika yang terjadi antara ajaran agama dengan kebudayaan-kebudayaan lokal penganutnya.
Dalam konteks budaya Jawa, fenomena dialektika tersebut menarik banyak akademisi untuk menelitinya. Bagaimana orang-orang Jawa mendialektikan antara Islam dan tata nilai budaya mereka. Di antara mereka membagi pendekatan terhadap Islam Jawa dengan dua model pendekatan. Pertama, ajaran Islam dan budaya Jawa dipahami sebagai dua kekuatan yang saling berhadapan dan berkompetisi dalam kehidupan masyarakat, yaitu satu sama lain saling menegasikan. Kedua, Islam dan Jawa dipahami secara sinkretis, yang menyatakan bahwa Islam dan Jawa berkembang secara beriringan, yaitu satu sama lain saling mengisi dan saling memberikan nilai dalam kehidupan masyarakat Jawa (Simuh, 1995: 173).

Hasil penelitian Clifford Geertz di kota yang disebutnya sebagai Mojokuto (Kediri), Jawa Timur, memberikan gambaran lapisan struktur masyarakat Jawa yang terdiri dari tiga varian, yaitu masyarakat abangan, priyayi dan santri. 
Kelompok abangan adalah struktur masyarakat yang menitikberatkan segi-segi sinkretisme Jawa secara total dalam setiap ritual dan kehidupan sehari-hari mereka yang berhubungan secara luas dengan unsur-unsur kaum petani di antara penduduk. Kaum santri merupakan gambaran struktur masyarakat yang menitikberatkan segi-segi Islam dalam sinkretisme yang pada umumnya berhubungan dengan kelompok pedagang dan petani; sedangkan priyayi adalah kelompok yang bersikap menitikberatkan pada segi-segi ajaran Hindu dan pada masa lalu berhubungan dengan unsur-unsur birokrasi dalam masyarakat Jawa (Geertz, 1960). Gambaran masyarakat Jawa seperti demikian sangat nampak dalam prosesiprosesi perkawinan dengan segala macam tradisi dan tata nilai yang hidup dalam masyarakat Jawa hingga masa kini.

\section{Metode Penelitian}

Metode penelitian yang digunakan dalam penelitian ini adalah kualitatif deskriptif yang bertujuan untuk memahami fenomena tentang apa yang dialami oleh subyek penelitian secara holistik dan dengan cara deskripsi dalam bentuk katakata dan bahasa, pada suatu konteks khusus yang alamiah dan dengan memanfaatkan berbagai metode alamiah (Moleong, 2005: 6). Penelitian ini bersifat deskriptif dengan maksud mengumpulkan informasi mengenai status suatu gejala yang ada yang bertujuan untuk membuat deskripsi, gambaran secara sistematis, aktual dan akurat mengenai fakta-fakta, sifat serta hubungan antar fenomena yang dimiliki (Arikunto, 1998: 309).

Dalam hal ini, peneliti bertujuan untuk menggali nilai-nilai yang hidup dalam masyarakat untuk menggambarkan secara sistematis, faktual dan akurat mengenai pandangan masyarakat muslim di Karangbesuki terhadap implementasi mahar dalam perkawinan mereka. Hal ini ditujukan untuk mengetahui sejauh mana masyarakat muslim di Karangbesuki Sukun, Kota Malang, mengaktualisasikan ajaran agama Islam dalam persoalan mengenai mahar, atau mas kawin, dalam perkawinan yang sudah menjadi tradisi di masyarakat.

Sumber data sebagai bahan utama dalam penelitian ini mencakup dua macam sumber yaitu (1) sumber data primer yang diperoleh secara langsung dari lapangan, seperti merekam dengan video/audio tapes, pengambilan foto, atau film berkenaan dengan kata-kata dan tindakan masyarakat muslim di Kelurahan Karang Besuki yang dipilih secara random dari 30 orang yang terdiri dari 15 orang laki-laki dan 15 orang perempuan; dan (2) sumber data sekunder yaitu data kepustakaan seperti dari jurnal ilmiah, majalah, laporan penelitian, buku, disertasi, dan tesis yang terkait dengan masalah mahar dalam berbagai mazhab.

Untuk pengumpulan data di lapangan penulis menggunakan teknikteknik yang lazim dimanfaatkan dalam penelitian lapangan yang meliputi sebagai berikut.

\section{1. Observasi dan Wawancara}

2. 1. 1. Observasi

Observasi dilakukan dengan cara melakukan pengamatan pada subyek penelitian atau atas fenomena-fenomena yang terjadi (Azwar, 1998: 19). Observasi tersebut dibagi menjadi dua yaitu (a) observasi terstruktur yaitu observasi yang telah terancang secara sistematis, tentang pandangan dan praktek penentuan mahar oleh masyarakat santri di Karangbesuki, 
Sukun Malang. Observasi tersebut dilakukan guna memperoleh data tentang pemahaman mereka terhadap nilai mahar yang mereka implementasikan dalam kehidupan sosial perkawinan mereka; dan (b) observasi tidak tersetruktur, yaitu observasi yang tidak dipersiapkan secara sistematis tentang apa yang akan diobservasi.

\section{1. 2. Wawancara}

Wawancara adalah usaha untuk mengumpulkan informasi dengan cara mengajukan sejumlah pertanyaan secara lisan. Ciri utama dari interview adalah terjadinya kontak langsung dengan bertatap muka antara si pencari informasi (interviewer atau information hunter) dengan sumber informasi. Secara sederhana interview dapat diartikan sebagai alat pengumpul data dengan menggunakan tanya jawab antara pencari informasi dengan sumber informasi. Interview dipergunakan untuk menghimpun data sosial, terutama untuk mengetahui tanggapan, pendapat, keyakinan, perasaan, motivasi dan cita-cita seseorang (Nawawi, 1998: 111). Wawancara dilakukan secara terstruktur serta dilakukan melalui tatap muka (face to face) dengan menggunakan pedoman wawancara yang telah tersusun secara sistematis dan lengkap untuk mengumpulkan data yang diperlukan.

\section{2. Teknik Analisis Data}

Dalam menganalisis data, penulis menggunakan analisis deskriptif, yaitu analisis data yang bertujuan untuk memberikan penjelasan mengenai subyek penelitian berdasarkan data yang diperoleh dari subyek yang diteliti, secara sistematis, faktual dan akurat (Brata, 1991: 19). Metode deskriptif dapat diartikan sebagai prosedur pemecahan masalah yang diselidiki dengan menggambarkan keadaan subyek atau obyek penelitian (seseorang, lembaga, atau kelompok masyarakat) pada saat sekarang berdasarkan fakta-fakta yang tampak atau sebagaimana adanya (Nawawi, 1998: 63). Dalam mempraktekkan metode analisis deskriptif ini, penulis menggunakan pendekatan sosiologis antropologis.

\section{Pengertian Mahar dalam Qur'an dan Hadits}

Menurut fuqaha, para ahli fiqih, mahar atau mas kawin adalah pemberian wajib dari calon suami yang menjadi hak calon isterinya, baik dalam bentuk benda maupun jasa, disebabkan akad nikah atau hubungan sebadan. Menurut Mazhab Maliki, mahar merupakan sesuatu yang menjadikan isteri halal untuk digauli; sedangkan menurut mazhab Syafi'i, mahar merupakan sesuatu yang wajib dibayar disebabkan akad nikah atau senggama. Menurut mazhab Hanafi, mahar merupakan jumlah harta yang menjadi hak isteri karena akad perkawinan atau disebabkan terjadinya senggama dengan sesungguhnya; sedangkan mazhab Hanbali mendefinisikan mahar sebagai imbalan suatu perkawinan baik disebut secara jelas dalam akad nikah, ditentukan setelah akad dengan persetujuan kedua belah pihak maupun ditentukan oleh hakim (Ghazali, 2006: 84; Aziz, 2000: 1042; Abidin dan Aminuddin, 1999: 105).

Pada dasarnya tidak ada nash yang menerangkan nominal mahar yang harus diserahkan seorang suami kepada isterinya. Dalam Q.S. An-Nisâ: 20, AlQur'an menyatakan, mahar sebagai qinthâr, yaitu menurut mufassir adalah sesuatu harta yang sangat banyak sepenuh kulit sapi yang telah dipotong (Sya'râwi, 
1997: 2085). Makna tersebut tidaklah memberikan gambaran spesifik mengenai nominal mahar yang harus diserahkan, sehingga ketika Khalifah 'Umar menetapkan ketentuan agar mahar tidak boleh melebihi 400 dirham dan apabila dilanggar maka kelebihan mahar tersebut akan disita untuk bait al-mâl, hal tersebut diprotes oleh seorang sahabat wanita dari Quraisy. Protes tersebut disandarkan kepada ayat di atas di mana kata qinthar tidak terbatasi oleh ketentuan 400 dirham yang ditentukan 'Umar R. A. Ketentuan tersebut akhirnya direvisi kembali oleh Umar R. A. di mana tidak ada batas maksimal untuk mahar (Al-Marâghi, 2000: 216).

Akan tetapi tidak berarti mahar dalam Islam harus diberikan dalam jumlah yang banyak dan memberatkan para lelaki. Banyak sekali hadits yang menyarankan kepada para wali untuk tidak bermahalmahal di dalam menentukan mahar untuk anak-anak perempuan mereka. Rasulullah saw. bersabda "sebaik-baiknya nikah adalah yang paling mudah." (Daud, 2004: 238).

Hadits terkait dengan anjuran meringankan mahar dalam pernikahan tentu merupakan sebuah bentuk keringanan kepada para pemuda yang baru saja menapaki masa produktifitas dalam bekerja. Mahar yang terlalu tinggi tentu akan memberatkan para pemuda sehingga memaksa mereka untuk menunda pernikahan. Apabila ini terjadi maka akan timbul masalah sosial di mana para pemuda akan mencari jalan untuk melampiaskan nafsu seksual mereka di tengah keterbatasan modal ekonomi yang mereka hadapi. Begitu juga pada pemudi akan merasa lama menanti pemuda yang sanggup untuk memberikan mahar yang diminta orang tua mereka selaku wali. ${ }^{1}$

Terkait dengan penentuan mahar maka pihak wanita maupun wali memiliki hak yang melekat dalam diri mereka. Hak seorang wanita dalam mahar adalah ketetapan diri mereka untuk menolak perkawinan yang ditentukan oleh wali mereka ketika maharnya kurang dari mahar yang sepadan dan layak untuknya (mahr mitsil). Hak ini melekat dalam diri mereka secara mutlak menurut Imam Syafi'i, sedangkan menurut Imam Abu Hanifah hak ini melekat apabila mereka adalah wanita yang sudah rasyîdah atau memiliki kematangan intelektual (AlZuhaily, 2005: 257).

Sedangkan hak seorang wali dalam masalah mahar menurut Imam Abu Hanifah berada dalam kasus ketika anak wanitanya menikah dengan seorang lakilaki tanpa sepengetahuannya dengan mahar yang kurang dari mahar yang selayaknya bagi anaknya, maka ia memiliki hak untuk mengajukan pembatalan pernikahan tersebut (AlZuhaily, 2005: 262).

Ketika mahar sudah diserahkan dalam akad pernikahan, maka secara mutlak mahar tersebut adalah milik isteri

\footnotetext{
${ }^{1}$ Kondisi ini menjadi masalah utama di negaranegara Arab dengan tingginya angka perawan tua dengan kisaran usia 20-30 tahun dan keterlambatan usia menikah para pemuda dan pemudinya. Beberapa riset menunjukkan angka anûsah (perawan tua) di negara-negara Arab sebagaimana berikut: Bahrain 25\% dari populasi wanita adalah perawan tua, Yaman $30 \%$, Kuwait, Qatar Libya $35 \%$, Mesir dan Maroko 40\%, Saudi dan Yordan $45 \%$, Aljazair $51 \%$, Tunisia 62\%, Iraq dan Syuriah70\%, Uni Emirat Arab 75\% dan tertinggi adalah Lebanon $85 \%$. Sulitnya wanita untuk mendapatkan suami adalah karena tingginya mahar yang harus diberikan seorang pria kepada calon isteri dan ketentuan lain yang menghambat pernikahan seperti larangan menikah dengan ras ataupun bangsa selain Arab. (http://www.topsarabia.com).
} 
di mana seorang wali tidak boleh membawanya tanpa seizin dari puterinya apabila ia sudah dewasa. Seorang isteri juga memiliki kebebasan untuk menggunakan mahar tersebut tanpa harus izin dan restu dari suaminya. Hak memiliki dan menggunakan mahar tersebut bersifat mutlak tanpa ada hal yang dapat menggugurkannya (Sabiq, 1977: 155). Seorang suami tidak boleh untuk meminta atau ikut menikmati mahar tersebut tanpa seizin dari isterinya.

\section{1. Pembayaran Mahar dalam Praktek Rasulullah dan Para Sahabat Nabi}

Pemberian mahar di dalam pernikahan sudah dipraktekkan pada masa sebelum risalah kenabian Muhammad S. A. W. Pada masa Rasulullah S. A. W. praktek tersebut diperbaiki dengan ditetapkannya mahar sebagai milik mutlak seorang wanita yang tidak boleh diganggu gugat oleh wali ataupun suaminya. Dalam setiap pernikahannya Rasulullah S. A. W. pasti memberikan mahar kepada isteri-isteri Beliau.

Adapun para sahabat di dalam pemberian mahar sangatlah beragam tergantung kondisi dan keadaan ekonomi masing-masing. Sahabat Ali R.A. ketika menikah dengan Sayyidah Fatimah R.A. memberikan perisai baju perangnya (AlAtsqolani, 2000: 84). Dalam banyak hadits yang lain Rasulullah saw membolehkan para sahabat untuk memberikan mahar berupa sepasang sandal. Hal tersebut terjadi pada seorang wanita di Bani Fazarah yang dinikahi dengan mahar berupa dua sandal. Rasulullah saw bertanya kepada wanita tersebut, "apakah engkau rela dengan mahar tersebut?" Wanita tersebut menjawab, "iya." Rasulullah saw pun memperbolehkan perkawinan tersebut (Al-Tirmidzi, 1975: 413).

Meskipun demikian, para ahli hukum Islam berbeda pendapat mengenai batasan minimum dan maksimum mahar sebagaimana berikut. Pertama, pendapat Imam Abu Hanifah yang menetapkan batas minimum mahar adalah 10 dirham dan yang senilai dengannya, sedangkan mahar maksimum adalah 500 dirham. Dasar dari pendapat tersebut adalah hadits Rasulullas saw yang mengatakan,. "tidak ada mahar yang kurang dari sepuluh dirham" (Al-Zuhaily, 2005: 229).

Imam Abu Hanifah juga mengkiyaskan ketentuan tersebut dengan batas minimum nishab pencurian yang berhak dipotong tangan. Ketentuan tersebut merupakan salah satu bentuk penghargaan terhadap kedudukan seorang wanita. Oleh karena itu semua hadits yang menceritakan mahar-mahar yang rendah harus ditafsirkan sebagai bentuk mahar yang kontan di mana setelah itu ia harus memberikan mahar sesuai dengan nominal yang selayaknya. Hal tersebut tercermin dari kasus 'Ali R. A. ketika akan menikahi Fatimah R. A. oleh Rasulullah perintahkan untuk memberikan Fatimah mahar berupa baju perang (Daud, 2000: 240).

Ketentuan mahar harus berupa mâl atau harta juga merupakan perintah Allah S. W. T. dalam Q.S Al-Nisa: 24. Penafsiran mengenai makna mâl dalam ayat tersebut harus diijtihadi sama dengan batas minimum nishab pencurian yaitu 10 dirham dan hal tersebut merupakan pilihan yang lebih menyakinkan dalam berijtihad mengenai batas minimum mahar (AlKasâni, 1986: 276).

Berikutnya, pendapat Imam Malik yang menetapkan minimum mahar adalah seperempat dinar atau senilai dengan 3 dirham. Dasar dari pendapat Imam Malik 
adalah sama dengan Imam Abu Hanifah, hanya saja Imam Malik berpendapat bahwa nishab terendah dalam hukuman potong tangan bagi pencuri adalah 3 dirham bukan 10 dirham, sebagaimana pendapat Imam Abu Hanifah. Pendapat tersebut juga merupakan pendapat $\mathrm{Sa}$ 'id Ibn al-Musayyab Rabi'ah dan Ibn Syihab yang merupakan tokoh-tokoh fiqh Kota Madinah (Al-Qurtubi, 1980: 551).

Kemudian pendapat Imam Syafi'i dan Ahmad Ibn Hanbal bahwa mahar dalam pernikahan tidak ada batas minimum ataupun maksimum. Dalam pandangan mereka segala sesuatu yang dapat dijadikan obyek jual beli maka ia dapat dijadikan sebagai mahar baik banyak ataupun sedikit. Dalil mereka adalah, tidak adanya ayat yang secara eksplisit menerangkan hal tersebut. Begitu juga riwayat-riwayat hadits yang menggambarkan beraneka ragamnya jenis dan nominal mahar yang semuanya tidak dapat diartikan sebagai mahar muajjal. Mahar yang terlalu mahal menurut ulama Syafi'iyyah akan menyebabkan terjadinya kemadharatan dan kebencian antara seorang laki-laki dengan wanita ataupun keluarganya. Meskipun demikian Ulama Syafi'iyyah mensunnahkan agar mahar tidak kurang dari 10 dirham dan tidak melebihi dari 500 dirham, sebagaimana pendapat Imam Abu Hanifah. Hal ini berdasarkan hadits yang diriwayatkan oleh Sayyidah Aisyah R. A. mengenai mahar Rasulullah saw kepada isteri-isteri Beliau dan merupakan sebuah keberkahan tersendiri apabila seorang laki-laki dapat mengikuti sunnah Rasulullah saw dalam pemberian mahar meskipun itu bukan merupakan kewajiban (Al-Syairâzy, 1999: 462).

Perbedaan para fuqaha, ahli fiqih, mengenai jumlah nominal mahar di atas berdasar kepada dua perbedaan dalam memahami posisi mahar dalam perkawinan. Perbedaan yang pertama terkait dengan keberadaan mahar dalam perkawinan apakah merupakan ganti atas kehalalan suami dalam menggauli calon isteri atau mahar merupakan suatu bentuk ibadah yang sudah ditentukan waktu penyerahannya. Jika mahar merupakan ganti maka tidak ada masalah terkait dengan sedikit banyaknya mahar sama halnya dengan ganti dalam jual beli yang terpenting adalah adanya keridhaan dari kedua belah pihak. Adapun ketika mahar merupakan ibadah yang tidak boleh digugurkan dengan keridhaan antara kedua belah pihak maka jumlah nominalnya pun harus dibatasi sebagaimana ayat-ayat yang menunjukkan hal tersebut secara tersirat. Sedangkan perbedaan yang kedua dalam memandang mahar adalah melihat kemungkinan adanya qiyas atau analogi hukum di dalam menentukan batasan minimum mahar (Rusyd, 2004: 46).

Meskipun demikian perbedaan tersebut pada hakekatnya dapat dikompromikan dengan adanya kesunnahan yang diambil oleh mazhab Syafi'i yang ukurannya sama dengan apa yang menjadi pendapat dari Imam Abu Hanifah. Hal tersebut mengacu kepada kaidah fiqhiyyah yang menerangkan kesunnahan untuk meninggalkan perselisihan. Dengan demikian tetap merupakan suatu kebaikan apabila seorang laki-laki mampu dan memiliki kemauan untuk memberikan mahar sesuai dengan standar minimum dan maksimum yang telah ditentukan oleh para fuqaha dari dalil-dalil al-Qur'an ataupun sunnahsunnah Nabi Muhammad S. A. W.

Dengan demikian, secara konseptual Islam memberikan kerangka 
konseptual mahar dalam perkawinan sebagaimana berikut.

(1). Seorang wali dan calon isterilah pihak yang paling berkompeten dalam menentukan nominal mahar yang akan diberikan oleh calon suami.

(2). Mahar akan menjadi milik mutlak seorang isteri di mana tidak ada pihak manapun yang mengambilnya.

(3). Pada tradisi Arab pada umumnya sebagaimana sunnah Rasulullah S. A. W., nominal mahar tidak kurang dari 10 dirham dan tidak lebih dari 500 dirham.

Ketiga aspek nilai konseptual mahar yang penulis gali dalam kehidupan beragama masyarakat santri di Karangbesuki, Kota Malang, untuk melihat sejauh mana mereka mengartikulasikan nilai-nilai mahar yang ada dalam ajaran agama dalam kehidupan perkawinan mereka.

\section{Nilai Konseptual Mahar dalam Praktek Perkawinan Masyarakat Muslim di Karangbesuki, Kota Malang}

Terkait dengan pemahaman masyarakat mengenai posisi mahar dalam perkawinan, mayoritas masyarakat menganggap mahar sebagai syarat perkawinan yang lebih bersifat ritual, padahal pada hakekatnya fuqaha berpendapat bahwa mahar bukanlah merupakan syarat sah perkawinan melainkan merupakan bentuk kewajiban dan konsekwensi dari akad nikah yang mengikat seorang laki-laki meskipun si perempuan sudah rela menikah dengan tanpa adanya mahar. Hal tersebut merupakan perintah Allah yang secara jelas diterangkan dalam beberapa ayat Al-Qur'an. Akad nikah tanpa maharpun sesungguhnya sah akan tetapi setelah akad seorang suami tetap harus memberikan mahar kepada isterinya.
Hanya Imam Malik saja yang menetapkan mahar sebagai rukun dalam perkawinan yang keberadaannya dapat menentukan sah atau tidaknya perkawinan.

Sedangkan dalam pratek pemberian mahar kebanyakan dari isteri hanya menerima mahar di bawah seratus ribu rupiah, kebanyakan dari mereka memberi atau menerima mahar Rp. 50.000,00-, bahkan separo dari responden hanya memberikan uang mahar sebesar Rp. 10.000. Dengan demikian mahar yang diberikan sangatlan kecil di bawah standar kesunnahan mahar menurut Imam Syafi'i dan kewajiban menurut Imam $\mathrm{Abu}$ Hanifah. Batas minimum mahar sebagaimana telah dibahas adalah berupa 10 dirham. Jika melihat tahun perkawinan yang rata-rata berada di tahun 1980an dan 1990an maka jelas sangalah jauh nominal mahar tersebut dari jumlah ideal. Sebagaimana diketahui bahwa 10 dirham adalah sama nilainya dengan 1 dinar sedangkan 1 dinar setara dengan emas 4,25 gram. Melihat harga emas pada tahun 1980an mencapai sekitar Rp.11.500/gram, sehingga nominal mahar yang ideal sesuai dengan kesunnahan ataupun kewajiban menurut ulama yang lain adalah di kisaran Rp. 50.000,00,-. Fenomena stagnansi mahar pada kisaran Rp.100.000,00 juga masih menjadi tradisi masyarakat pada tahun 2018, padahal melihat harga emas yang berada pada kisaran Rp.500.000,00,maka kesunnahan pembayaran mahar berada pada kisaran Rp. 2.000.000,00- ke atas, tidak tetap pada nominal Rp. 100.000,00-. Rendahnya nominal mahar yang diserahkan pada saat pernikahan kepada isteri tidak berbanding lurus dengan besarnya biaya lain dalam pernikahan, yang sesungguhnya tidak memiliki kaitan yang erat dengan akad nikah tersebut seperti mahalnya biaya 
menyewa teratak, sound system dan lain sebagainya. Rendahnya nominal mahar tersebut bisa jadi merupakan bentuk penafsiran dari hadits yang menyatakan keberkahan mahar terletak pada mahar yang mudah atau ringan tanpa melihat konteks hadits tersebut disabdakan oleh Rasulullah saw pada masyarakat Arab yang berlomba-lomba dalam meninggikan mahar sehingga menyulitkan dan kaum perempuan untuk menemukan suami yang bersedia. Penentuan mahar yang tinggi tersebut adalah oleh para wali yang mengambil keuntungan dari mahar tersebut. Uniknya dari 30 orang suami yang diwawancara, 21 (70\%) orang suami melihat mahar yang sudah ia berikan sudah ideal, dan dalam pandangannya hanya 6 $(20 \%)$ orang suami yang menyadari rendahnya mahar yang ia berikan kepada isterinya; sedangkan 3 (10\%) orang suami merasa bahwa mahar yang diberikan kepada isterinya sudah cukup.

Dalam hal ini masyarakat Jawa pada umumnya berbeda dengan suku lainnya yang beragama Islam seperti di Betawi ataupun Bugis yang menetapkan mahar setinggi-tingginya karena itu terkait dengan harga diri pihak wanita yang akan dinikahi di mana semakin tinggi mahar yang diterima menunjukkan ketinggian status sosialnya di masyarakat.

Di sisi lain, mahar yang dalam Islam telah ditetapkan sebagai hak perogatif seorang wanita ataupun walinya, akan tetapi dalam proses pernikahan yang dilakukan oleh responden, $80 \%$ dari nominal mahar tersebut ditentukan sendiri oleh calon suami tanpa ada perundingan atau persetujuan dari pihak perempuan ataupun walinya. Dalam konteks fiqh, pihak calon isterilah yang memiliki hak untuk menentukan besaran mahar yang akan dia terima, bukan calon suami.
Dengan demikian si wanita dapat memberikan dan menentukan mahar yang dirasa akan membawa manfaat kepada dirinya sebagai individu ataupun isteri dan ibu untuk menunjang kebutuhan hidup ataupun gaya hidupnya sehari-hari.

Penentuan mahar tersebut memang sangat dipengaruhi oleh tradisi masyarakat di Jawa yang memang tidak memandang mahar sebagai sesuatu yang urgen dalam akad pernikahan sehingga ia hanya merupakan seremoni formalitas yang ada dalam akad, dan tidak lebih dari itu. Hal tersebut tercermin dari jawaban responden di dalam menentukan mahar ketika akad nikah. Dalam pemanfaatan mahar 50\% responden menggunakannya untuk kebutuhan bersama seperti membeli bumbu dapur, perkakas rumah tangga sedangkan $50 \%$ yang lain memberikannya kepada isteri sepenuhnya. Ada kepercayaan dalam masyarakat bahwa mahar merupakan harta yang berkah sehingga sangat baik untuk dibelikan dan dibelanjakan keperluan rumah tangga. Kepercayaan tersebut tidaklah berasal dari ajaran agama akan tetapi lebih banyak kepada pengaruh adat masyarakat setempat. Di dalam Al-Qur'an Allah swt melarang suami meminta kembali mahar yang telah ia berikan kecuali apabila si isteri benar-benar rela maka tidak masalah bagi suami ikut menikmatinya. Para fuqaha memberikan batasan kerelaan tersebut harus benar-benar ke luar dari lubuk hati seorang isteri, tidak karena takut ataupun paksaan.

Wanita suku Jawa menurut para responden adalah orang yang nriman sehingga mereka merasa tidak layak untuk meminta mahar yang berlebihan. Hal tersebut berbeda dengan masyakat pada suku Betawi ataupun di luar Jawa seperti Nusa Tenggara Barat yang menjadikan 
mahar sebagai bentuk penghargaan bahkan kebanggaan kepada wanita dalam pernikahan. Dengan demikian sangat wajar apabila mahar di daerah-daerah tersebut sangatlah tinggi. Meskipun responden yang lain melihat rendahnya nominal mahar pada masyarakat Jawa lebih disebabkan kepada rendahnya tingkat ekonomi mereka. Hal ini meskipun berpengaruh akan tetapi jika dianalisa tidak merupakan faktor yang dominan dikarenakan pada masyarakat yang memiliki kemampuan menengahpun nominal mahar tidaklah tinggi.

Terkait dengan standarisasi nominal mahar, mayoritas responden tidak menyetujui hal tersebut secara mutlak dengan alasan itu akan membebani calon suami sehingga menyebabkannya akan mengurungkan niat untuk menikah sebab tingginya biaya pernikahan meskipun secara faktual banyak dari mereka mampu untuk menyelenggarakan dan menyewa fasilitas perkawinan yang lebih mahal dari nilai mahar yang diberikan, seperti sound system dan lain sebagainya, yang tidaklah merupakan hal yang dianjurkan dalam proses perkawinan apalagi diwajibkan.

Pandangan tersebut lebih banyak didasarkan kepada pemahaman nilai yang ada di masyarakat yang menyakini bahwa mahar hanyalah bentuk dari simbolisasi perkawinan, tidak lebih dari itu, apalagi dipandang sebagai nominal untuk menjualbelikan wanita. Pemahaman tersebut terinternalisasi secara baik pada semua pihak baik wali, mempelai perempuan ataupun mempelai suami.

\section{Simpulan}

Dalam tradisi masyarakat santri di Kelurahan Karangbesuki, Kecamatan Sukun, Kota Malang, penentuan nominal mahar lebih banyak dilakukan oleh calon suami, berbeda dengan konsep dalam fiqh yang meletakkan hak penentuan mahar pada pihak isteri dan wali. Meminta mahar tertentu dalam pandangan mereka merupakan hal yang tabu karena dalam pandangan mereka mahar hanyalah aspek seremonial dalam perkawinan. Pada pemanfaatannya mahar digunakan oleh isteri untuk membeli kebutuhan dapur pada awal pernikahan dengan kenyakinan bahwa hal tersebut akan memberikan keberkahan dalam rumah tangga, berbeda dengan konsep fiqh yang menjadikan mahar sebagai hak mutlak isteri yang tidak dapat diganggu gugat oleh siapapun. Masyarakat memahami untuk menetapkan mahar seringan mungkin agar tercipta keluarga yang harmonis terlepas adanya ketentuan batas minimum mahar dalam figh yang mereka anut. Praktek tersebut merupakan bentuk dialektika yang mereka pahami untuk menyesuaikan konteks hukum fiqh dan budaya dalam perkawinan mereka.

\section{Daftar Pustaka}

Abidin, Slamet \& Aminuddin. 1999. Fiqih Munakakat. Bandung: Pustaka Setia.

Al-Atsqalâni, Ibnu Hajr. 2000. Bulûgh al-Marâm. Riyadh: Dâr Athlas.

Al-Kasâni. 1986. Badâi' alShanâi'. Beirut: Dâr al-Kutub al-'Ilmiyah.

Al-Marâghi. 2000. Tafsîr alMarâghi. Kairo: Musthafa al-Halaby.

Al-Syairâzy. 1999. Al-Muhadzab fi Fiqh al-Imâm al-Syâfi'i. Beirut: Dâr alKutub al-Ilmiyah. 
Al-Tirmidzi. 1975. Sunan alTirmidzi. Mesir, Musthafa al-Bâby alHalaby.

Al-Qurtûby, 'Âshim al-Namry. 1980. al-Kâfi fì Fiqh Ahl al-Madînah. Riyâdh: Maktabah Riyâdh al-Hadtîsah.

Al-Zuhaily, Wahbah. 2005. al-Fiq al-Islâmy wa Adillatuh. Beirut: Dâr alFikr.

Arikunto, Suharsimi. 1998. Manajemen Penelitian. Jakarta: Rineka Cipta.

Aziz, Dahlan Abdul. 2000. Ensiklopedi Hukum Islam. Jakarta: Ikhtiar Baru Van Hoeve.

Azwa, Syaifudin R. 1998. Metode Penelitian. Yogyakarta: Pustaka Pelajar.

Brata, Sumadi Surya. 1991. Metodologi Penelitian. Jakarta: C. V. Rajawali.

Daud, Abu. 2004. Sunan Abi Daud. Beirut: Maktabah al-'Ashriyyah.

Geertz, Clifford. 1960. The Religion of Java. Glencoe, Illinois: Free Press.

Ghazali, Abd Rahman. 2006. Fiqh Munakakat. Jakarta: Kencana.

Kuntowijoyo. 1996. Paradigma Islam, Intrepretasi untuk Aksi. Bandung: Mizan.

Moleong, Lexy J. 2005. Metodologi Penelitian Kualitatif. Bandung: Rosda Karya.
Nawawi, Hadari. 1998. Metode Penelitian Bidang Sosial. Yogyakarta: Gadjah Mada University Press.

Rusyd, Ibn. 2004. Bidâyat alMujtahid. Kairo: Dâr al-Hadîth.

Sabiq, Sayyid. 1977. Fiqh alSunnah. Beirut: Dâr al-Kitâb al-'Araby.

Simuh. 1995. Sufisme Jawa: Transformasi Tasawuf Islam dalam Mistik. Yogyakarta: Bentang.

Sya'rawi. 1997. Tafsîr al-Sya'rawi. Kairo: Akhbar al-Yaum. 